PRACE NAUKOWE UNIWERSYTETU EKONOMICZNEGO WE WROCLAWIU

\title{
Dominika Porowska
}

Uniwersytet Łódzki

e-mail: d.porowska@gmail.com

\section{KIERUNKI ROZWOJU BADAŃ KONSUMENCKICH W ŚWIETLE ZALOŻEŃ EKONOMII BEHAWIORALNEJ \\ DEVELOPMENT DIRECTIONS \\ OF CONSUMER RESEARCH IN THE LIGHT OF BEHAVIORAL ECONOMICS}

DOI: $10.15611 /$ pn.2016.459.07

JEL Classification: M10

Streszczenie: Coraz częściej mówi się o nowej erze myślenia o konsumencie. Zaczyna się go postrzegać przez pryzmat jego umysłu i zachodzących w nim procesów. Zmienia to znacznie podejście do badań konsumenckich, których tradycyjne metody, szczególnie ilościowe, przestają być adekwatne. Chęć zrozumienia prawdziwych motywacji konsumenta, w świetle tez głoszonych przez ekonomistów behawioralnych, wymaga stosowania metod złożonych, które skupią się na umyśle i tym, co nieuświadomione, nieracjonalne i oparte na neurologicznych reakcjach. Obok badań jakościowych popularność zyskują więc badania oparte na procesach neurologicznych, które dają szerszy obraz tego, co dzieje się w umyśle konsumentów. W artykule, opartym na literaturze przedmiotu, wskazano kierunki rozwoju badań konsumenckich w świetle osiągnięć ekonomii behawioralnej i neuromarketingu. Zaprezentowano wybrane techniki prowadzenia badań, które pozwalają szerzej spojrzeć na nieuświadomione potrzeby i motywacje konsumentów.

Słowa kluczowe: badania marketingowe, badania jakościowe, ekonomia behawioralna, neuromarketing.

Summary: The new era of understanding a consumer's behavior has arrived. Nowadays we look at a consumer taking into account psychical and brain's processes rather than perceiving his/her behavior in a traditional way. This approach affects the way we treat marketing research: traditional methods appear to be insufficient. To understand a consumer's mind, first we need to understand all processes pertaining to the brain. This is strictly connected with behavioral economics. In spite of qualitative research all processes connected with neuroscience are currently increasingly getting into business focus. Based on the literature analysis as well as taking into account the growing importance of both behavioral economics and neuromarketing, the goal of this paper is to present directions of marketing research development. This is an attempt to point out a couple of methods how to conduct studies that can discover either motivations or unconscious needs of a consumer.

Keywords: marketing research, qualitative study, behavioral economics, neuromarketing. 


\section{Wstęp}

Nie ulega wątpliwości, że badania marketingowe są kluczowym elementem działań rynkowych. Stwierdzenie to ma szczególne znaczenie dziś, w czasach, które charakteryzuje zmienność i turbulentność. Oznacza to, że decyzje rynkowe, marketingowe podejmowane są również w warunkach niepewności i ryzyka, co wiąże się nierozłącznie z szybkością i głębokością zmian, jakie zachodzą w otoczeniu organizacji [Gregor, Kalińska-Kula 2015]. Odpowiedzialni za podejmowanie kluczowych decyzji, w obliczu konkretnych wyzwań, wyborów, problemów, zgłaszają zapotrzebowanie na określone informacje [Gregor, Kalińska-Kula 2015], a więc element wiążący daną organizację z jej rynkowym otoczeniem [Kotler i in. 2002]. Znaczna część definicji pojęcia „badania marketingowe” do niego właśnie odwołuje się w pierwszej kolejności. Czyni to na przykład American Marketing Association, podkreślając, że informacje wykorzystywane są do identyfikowania i określania problemów i możliwości marketingowych, do tworzenia, doskonalenia i oceny działań marketingowych, do monitorowania efektów tych działań oraz do lepszego poznawania procesów marketingowych [Kotler i in. 2002]. Podaje się również, że badania marketingowe obejmują diagnozę potrzeb informacyjnych przedsiębiorstwa, selekcję zmiennych oraz gromadzenie, analizowanie i interpretowanie danych służących do podejmowania decyzji rynkowych [Mazurek-Łopacińska (red.) 2005]. Większość definicji, oprócz nacisku na rolę informacji, wskazuje również decyzyjny aspekt prowadzenia badań marketingowych, jako cel podając wsparcie procesów decyzyjnych poprzez ograniczenie zakresu subiektywnych przesłanek oraz oparcie zarządzania marketingiem na bezstronnych i dokładnych podstawach, czyli rezultatach badań przeprowadzonych według określonych zasad metodologicznych [Grzegorczyk 2014]. Oznacza to zatem, że badania marketingowe są tym dla marek, czym mikroskop dla naukowca. Pozwalają przyjrzeć się bieżącej sytuacji rynkowej i wyciągnąć wnioski, które następnie staną się fundamentem przemyślanej i skrupulatnie zaplanowanej strategii marki, lub pomogą znaleźć odpowiedź na nurtujące pytania. Rozwiązanie wielu problemów decyzyjnych wymaga różnych danych, a zwłaszcza informacji o rynkach.

Wobec przedstawionych definicji, kluczowe wydaje się zatem pytanie, jakich informacji organizacje dzisiaj potrzebują do podejmowania decyzji rynkowych - co w czasach, w których światem rządzi gospodarka oparta na wiedzy [Hejduk 2010], będzie dla nich naprawdę przydatne $\mathrm{i}$ istotne $\mathrm{z}$ punktu widzenia budowania przewagi rynkowej? Jak wskazuje teoria, jednym z celów badań marketingowych jest wyjaśnienie mechanizmu zachowań podmiotów rynku oraz zidentyfikowanie środków umożliwiających oddziaływanie na te zachowania [Mazurek-Łopacińska (red.) 2005]. Można więc stwierdzić, że najważniejszą częścią tego, co składa się na całościowy obraz bieżącej sytuacji, jest konsument - odbiorca wszystkich działań podejmowanych w organizacjach, adresat komunikatów i ostatni element łańcucha, który weryfikuje słuszność podjętych decyzji i wypracowanych założeń. Współcześnie 
wiedza o cechach charakteryzujących grupę docelową, a więc konsumentów, jest podstawą tworzenia oferty produktowej, kreowania nowych produktów czy wreszcie kształtowania relacji między konsumentem a organizacją, jak również pozostałych działań marketingowych. Jest też jednym z fundamentów analiz naukowych, które pozwalają określić zmiany, jakie obserwuje się w zachowaniach odbiorców [Dąbrowska, Wódkowski 2014]. Poszukiwanie insightów konsumenckich, a więc fragmentów wiedzy pochodzących od klientów na temat ich samych [Kozielski 2013], staje się jednym z ważniejszych wyzwań, które pozwalają zrozumieć sposób myślenia odbiorcy wszelkich komunikatów i adresata wszelkich działań. Ma to fundamentalne znaczenie, bowiem konsument podejmuje szereg różnorodnych decyzji, będących konsekwencją oddziaływania niezliczonych zmiennych. Zmienne te są niejednoznaczne i najczęściej nie dają się przewidzieć [Niemczyk 2004]. Coraz częściej znaczącą rolę w rozumieniu klientów odgrywają pozaekonomiczne dziedziny nauk. Spojrzenie na zjawiska zachodzące w biznesie przez pryzmat psychologii dało początek nowemu nurtowi nauki - ekonomii behawioralnej, która podkreśla rosnące znaczenie postaw psychologicznych, zarówno teoretycznych, jak i praktycznych [Wiśniewski, Brzezicka 2013], w ekonomii.

Zachowania konsumentów i współczesne podejście do badań marketingowych ma więc wiele wspólnego. Liczne zależności, które łączą te dwa obszary [Hall 2014] stają się szansą na budowanie takiej propozycji wartości, która zapewni organizacjom przewagę konkurencyjną. Celem poniższego artykułu jest przegląd metod prowadzenia badań marketingowych, które, w świetle ekonomii behawioralnej i, szerzej, psychologicznego spojrzenia na konsumenta, pozwalają uzyskać kluczowe informacje do podejmowania decyzji rynkowych.

\section{Nowe spojrzenie na konsumenta - perspektywa ekonomii behawioralnej}

Najważniejszymi zagadnieniami w badaniach nad zachowaniami konsumentów wydaje się obserwowanie, a następnie analiza procesów, jakimi kierują się ludzie podczas podejmowania decyzji zakupowych. Zachowanie rynkowe klientów warunkują doświadczenia z przeszłości, przewidywanie przyszłości oraz przypadkowy dopływ bodźców w teraźniejszości [Kuś 2011]. W tradycyjnym rozumieniu, konsument postrzegany jest jako jednostka racjonalna, która podejmuje decyzje z perspektywy ekonomicznej, swoje wybory opierając na czynnikach marketingowych (specyfice produktu, cenie, dystrybucji) oraz ekonomicznych, z których najważniejszym wyznacznikiem wydają się zasoby finansowe konsumenta.

Nieco inną perspektywę, opartą na irracjonalności i podświadomych procesach, przyjmują ekonomiści behawioralni. Punktem wyjścia do ich rozważań są wzajemne interakcje oraz przenikanie się trzech płaszczyzn działań konsumenta: zachowania, wyboru oraz decydowania [Brzezicka 2012]. Wszystkie aspekty poruszane przez specjalistów opierają się jednak na tym elemencie, który pozwala ludziom funkcjo- 
nować i rozumieć otaczającą ich rzeczywistość i w którym zachodzą procesy w sposób podświadomy i przez długi czas nieuchwytny - na mózgu i umyśle. To właśnie tam zachodzą reakcje na bodźce, które odpowiedzialne są za podejmowane decyzje zakupowe.

Daniel Kahneman, noblista, jeden z ojców ekonomii behawioralnej, zwraca uwagę na to, co znajduje się w ludzkiej czaszce, odbiegając znacznie od wizji neurologicznej dwóch półkul. Proponuje on, by spojrzeć na mózg jako na dwa współistniejące systemy - System 1 i System 2. Ich działanie pozwala wyjaśnić, czym kieruje się człowiek w codziennym życiu. System 1 to tak zwane myślenie szybsze - myślenie intuicyjne, czyli fachowe, oraz myślenie heurystyczne, a także zupełnie automatyczne formy umysłowej aktywności, takie jak percepcja czy pamięć. System 2 natomiast utożsamiany jest z myśleniem wolnym, z którym mamy do czynienia wtedy, kiedy żadne intuicyjne rozwiązanie nie przychodzi do głowy, co zmusza jednostkę do większego wysiłku umysłowego, jednak nie większego niż to absolutnie konieczne [Kahneman 2011].

Podział ten jest niezwykle istotny w obliczu założeń przedstawionych przez przedstawicieli nurtu ekonomii behawioralnej. Uważa się bowiem, że człowiek ma skłonność do przeceniania swojego zrozumienia rzeczywistości, a niedoceniania roli, jaką w rozwoju wydarzeń odgrywa przypadek [Kahneman 2011]. Człowiek sam nie jest świadomy procesów, jakie zachodzą w jego umyśle, ani nie potrafi zmierzyć, w jakim stopniu wpływają one na jego zachowanie. Co dla badaczy, którzy analizują postawy konsumentów, niezwykle istotne, nie przeszkadza to jednostce $\mathrm{w}$ nieustannym usprawiedliwianiu swoich zachowań poprzez przedstawianie, wydawałoby się logicznych, przesłanek. Konsument postrzega swoje akcje jako w pełni sterowalny i podlegający kontroli proces. W rzeczywistości jest zupełnie odwrotnie, co stanowi kluczową informację dla prowadzenia wszelkich badań rynkowych [Graves 2010].

\section{Rosnąca rola badań jakościowych}

Stąd właśnie na uwagę tych, których celem jest zrozumienie konsumenta, jego postaw, opinii, zwyczajów i potrzeb, oraz analiza barier i motywów związanych z używaniem produktów i marek [Maison 2010], zasługują przede wszystkim badania jakościowe. Wykorzystują one w dużym stopniu wywiady indywidualne i grupowe, w różnej formie, starając się skoncentrować raczej na różnorodności zjawisk niż na częstotliwości ich występowania [Maison 2010]. Zadawane pytania mają więc charakter eksploracyjny, a analiza i interpretacja ich wyników cechuje się subiektywizmem i brakiem jednoznacznych kryteriów analizy. Badania jakościowe służą przede wszystkim rozumieniu rzeczywistości i dają możliwość wyciągania wniosków o szerokim zakresie [Maison 2010].

Właściwie we wszystkich metodach o charakterze jakościowym istotne dla badacza są informacje płynące nie tylko z komunikatów werbalnych (wypowiadane 
deklaracje), ale również, a może przede wszystkim tych niewerbalnych [Kaczmarek, Olejnik, Springer 2013]. Dokonuje się analizy zawartej w gestach, postawie ciała czy mimice respondentów [Kaczmarek, Olejnik, Springer 2013]. Są szczególnie istotne, stanowią bowiem odpowiedź na zjawisko intelektualnego alibi. Cechą charakterystyczną ludzkiej świadomości jest skłonność do tłumaczenia zachowania po fakcie, a nie kierowanie nim [Zaltman 2003]. I to intelektualne alibi właśnie pozwala człowiekowi tłumaczyć swoje reakcje poprzez odwołanie się do tak zwanego dobrego powodu. Dzięki temu konsumenci racjonalizują oparte na emocjach decyzje, które zostały podjęte w sposób nieświadomy [Hill 2010].

Bardzo duże znaczenie dla zrozumienia zachowań konsumenckich i procesu podejmowania decyzji zakupowych mają, obok tradycyjnych wywiadów grupowych lub indywidualnych, techniki projekcyjne. Choć jest to narzędzie, które swoją genezę ma w psychiatrii, coraz częściej wykorzystuje się je również przy badaniach marketingowych. Jako że w postawach konsumenckich wiele jest obszarów nieuświadomionych, z których konsument nie zdaje sobie sprawy i nie potrafi wyrazić ich słowami, zdecydowanie skuteczniejsze są te metody, w wyniku których potrafi on przypisać otoczeniu pewne cechy, uczucia i pragnienia [Maison 2010]. W marketingu projekcja rozumiana jest raczej jako subiektywne nadawanie znaczenia otoczeniu [Maison 2010]. Techniki projekcyjne stosuje się, by zrozumieć sposób postrzegania konsumentów, zidentyfikować ich potrzeby czy wyobrażenia na temat produktu, marki lub reklamy [Maison 2010]. Są kluczowe dla problemów, w których badana osoba może nie zdawać sobie sprawy z rzeczywistych powodów własnego zachowania, lub też gdy zagadnienie, którego badanie dotyczy, może być trudne do zwerbalizowania.

Przykładem najprostszych technik projekcyjnych są skojarzenia - mają one za zadanie wydobycie podświadomych znaczeń, reakcji emocjonalnych czy stereotypów związanych z daną marką, nazwą produktu czy nim samym [Kaczmarek, Olejnik, Springer 2013]. Ma to związek z psychologicznym rozumieniem procesu podejmowania decyzji, który podkreśla kluczową rolę działań nieświadomych i oddziaływania bodźców na umysł klienta.

Ciekawą techniką, mającą zastosowanie zarówno do badań indywidualnych, jak i grupowych, jest animalizacja. Polega ona na wyobrażeniu danego obiektu, na przykład marki, jako zwierzęcia. Opiera się na automatycznych skojarzeniach, nieprzemyślanych i intuicyjnych [Maison 2010]. Jest to technika bardzo przydatna do diagnozowania emocjonalnych skojarzeń związanych z markami. Ponadto może ona wiele wnieść w zrozumienie postrzegania osobowości marki [Maison 2010].

\section{Badania etnograficzne - świat marek oczami klienta}

Metodą badań jakościowych, na którą warto zwrócić szczególną uwagę, są badania etnograficzne. Etnografia, w ogólnym znaczeniu, oznacza naukę opisującą tradycyjną kulturę różnych ludów [Dunaj (red.) 1996]. W odniesieniu do marketingu można 
rozumieć to pojęcie raczej jako opis ludzi w ich naturalnym kontekście - $\mathrm{w}$ domu, miejscu pracy, na zakupach czy u lekarza. Pomaga wyjść ponad to, co przewidywalne, ku temu, co rzeczywiście odzwierciedla potrzeby ludzi [http://www.izmalkowa. com]. Opiera się na pracy w terenie i ma charakter spersonalizowany - badacze są zarówno uczestnikami, jak i obserwatorami życia społecznego będącego przedmiotem analizy [Angrosino 2010]. Co ważne, wymaga długotrwałego zaangażowania badacza, które pozwoli mu na właściwą interpretację wszystkich zarejestrowanych zjawisk [Angrosino 2010]. Etnografia jest sztuką i nauką skupioną na opisie grupy ludzkiej - jej instytucji, zachowań interpersonalnych, wytworów materialnych i przekonań [Angrosino 2010]. Chodzi więc o wejście w świat konsumenta, próbę zobaczenia świata marek i produktów jego oczami [Maison 2010]. Celem badań etnograficznych jest zdefiniowanie przewidywalnych wzorów zachowań grupy [Angrosino 2010], a więc odkrywanie insightów konsumenckich.

Cechą charakterystyczną badań etnograficznych jest nastawienie na eksplorację zjawisk, co wymaga od badacza otwartości wobec rzeczywistości i umiejętności odkrywania tego, co nie zostało określone wcześniej. Istotna jest również elastyczność pod względem metodologicznym i organizacyjnym [Maison 2010].

W czasach, w których technologia odgrywa znaczącą rolę w świecie biznesu, nie mogło zabraknąć odmiany badań etnograficznych, która stanowiłaby narzędzie idealne dla firm prowadzących działalność jedynie w Internecie. Mowa o etnografii wirtualnej, której celem jest poznawanie i opisywanie zjawisk na podstawie dających się zaobserwować w Internecie zachowań konsumentów [Jemielniak 2012].

Wiele jest rodzajów badań jakościowych. Każdy z nich to niezwykle cenne i warte uwagi narzędzie w pracy badacza - pozwala bowiem na zgłębienie ludzkiej natury. Daje szansę na zrozumienie tego, czym kieruje się konsument, wybierając dany produkty czy usługę. Badania jakościowe można rozumieć jako lekko uchylone drzwi do świata ludzkiego umysłu - marki mogą przez nie podejrzeć te elementy, których istnienia sam nabywca nie jest świadomy.

\section{Neurobiologia w służbie marketingu i biznesu}

Drzwi te można obecnie otworzyć znacznie szerzej, co zawdzięcza się ekonomistom behawioralnym i propagowanemu przez nich podejściu neurobiologicznemu do poszczególnych aspektów biznesu. W odniesieniu do analiz procesów myślowych i reakcji mózgowych coraz częściej mówi się o neuroekonomii, którą określa się jako naukę mającą na celu ugruntowanie ekonomicznych teorii w mechanizmach neuronowych [Szymusiak 2012]. Badania przeprowadzone na ludzkim mózgu pozwalają wykonać kolejny krok w zrozumieniu konsumenta, tym razem poszukując informacji u źródła wszelkich reakcji i decyzji.

Narzędziem badania przestaje w tym wypadku być kartka papieru, należy zapomnieć również o pewnym subiektywizmie, właściwym badaniom jakościowym. Używa się zaawansowanych technologicznie maszyn i urządzeń, które dają wgląd 
we wnętrze umysłu. Najpopularniejszą metodą jest obecnie neuroobrazowanie. Opiera się ono na analizie zmian, które obserwuje się w poszczególnych obszarach mózgu przy postawieniu badanych przed problemem w dwóch wariantach. Wariant eksperymentalny pozwala badać reakcje na konkretny produkt, komunikat czy obraz. Wariant kontrolny natomiast, pozornie niezwiązany bezpośrednio $\mathrm{z}$ badanym elementem, uwydatnia zmiany i różnice w reakcjach [Camerer, Loewenstein, Prelec 2015]. Pozwala to na ich porównanie i wyciągnięcie odpowiednich wniosków, na podstawie których podjęcie decyzji o zmianie w komunikacji danego produktu ma twarde, empiryczne podstawy, dostarczając tym samym relatywnie dużej ilości przydatnych informacji. Mówią one o tym, na które elementy człowiek lepiej zareaguje, które z nich oddziaływały na obszary mózgu odpowiedzialne za podejmowanie decyzji zakupowych, uczucie przyjemności czy satysfakcji.

Jedną z podstawowych metod neuroobrazowania jest badanie elektroencefalografem (EEG). Pozwala ono na analizę fal mózgowych poprzez rejestrację zmian aktywności elektrycznej kory mózgowej. Daje to możliwość śledzenia myśli i odczuć badanego. Widać w nim również zmiany, które zachodzą nawet, gdy w badaniu stosujemy szybko zmieniające się obiekty czy też, dla przykładu, sekwencję różnych ujęć zastosowanych w reklamie telewizyjnej. Pozwala to stwierdzić, które elementy wywołują silne emocje, zarówno pozytywne, jak i negatywne [Szymusiak 2012].

Narzędziem, które zastosować można komplementarnie do EEG jest funkcjonalny rezonans magnetyczny, tak zwane fMRI. Rezonans pozwala na obserwowanie aktywności całego mózgu, z wyszczególnieniem tych struktur, które w danym momencie są zaangażowane w podejmowanie interakcji z pozostałymi obszarami. Badanie to nie rejestruje zmian w czasie rzeczywistym, mimo to pozwala zlokalizować struktury odpowiedzialne za poszczególne procesy. Porównanie reakcji na czynnik eksperymentalny i kontrolny pozwala na dokładną analizę aktywności mózgu i różnic, jakie zachodzą przy każdym z wariantów badania [Szymusiak 2012]. Na tej podstawie można stwierdzić, jakie elementy angażują bardziej pożądane obszary, a więc emocje i odczucia, które następnie mogą decydować o dokonaniu bądź nie zakupu, będąc tym samym ważnym czynnikiem motywującym przy podejmowaniu decyzji.

Inną, prostszą i obecnie dość powszechną metodą badania reakcji konsumenta na poziomie nieświadomym jest eyetracking - technika oparta na aktywności okoruchowej. Dzięki specjalnym czujnikom śledzącym ruchy gałki ocznej pozwala stwierdzić, w którym dokładnie miejscu oko odbiorcy zatrzymało się najdłużej czy też który element komunikatu został wychwycony w pierwszej kolejności. Daje więc szansę na śledzenie drogi, którą pokonują informacje w procesie poznawczym [Camerer, Loewenstein, Prelec 2015]. Najczęściej metoda ta odnosi się do sfery digital, pozwalając badać reakcje na treści publikowane w Internecie. Ale nie jest to jedyne zastosowanie. Znanych jest już wiele metod, które pozwalają pobierać informacje nie tylko o właściwościach mechanicznych gałki ocznej, ale i optycznych czy elektrycznych [Szymusiak 2012]. 
W badaniach coraz częściej stosuje się również techniki określane jako psychofizjologiczne. Kryją się za tym metody dobrze znane, w medycynie wykorzystywane od zawsze, jednak w obszarze badań zachowań konsumenckich ich wykorzystanie nie jest tak oczywiste, jak mogłoby się wydawać. Odnoszą się one do badania rytmu serca, ciśnienia krwi, zmian skórnych czy mikroekspresji mięśni twarzy, a także do testów przeprowadzanych za pomocą wariografu czy kamery termowizyjnej. Metody te są chętnie wykorzystane jako uzupełnienie pozostałych, bardziej czasochłonnych i kosztownych technik, dostarczając dodatkowych informacji [Camerer, Loewenstein, Prelec 2015]. Te, w zestawieniu z wynikami badań wykorzystujących na przykład neuroobrazowanie, prowadzą do pełniejszego obrazu.

Powyższe techniki mogą okazać się bezcenne dla marketerów. Analiza wyników pozwala bowiem realnie spojrzeć w głąb ludzkiego umysłu i zweryfikować, jakie efekty przynoszą dotychczas stosowane metody. Pokazują one, w którym kierunku powinno się podążać, by jeszcze lepiej dopasować ofertę do rzeczywistych potrzeb konsumenta - tych nieuświadomionych, ukrytych w zakamarkach umysłu. I choć dzisiaj badania te nazywa się częściej neurologicznymi niż marketingowymi, wnikliwa analiza ich wyników rysuje przed marketerami i menedżerami zupełnie nowe horyzonty. Daje im do ręki narzędzia, dzięki którym będą mogli tak zaprojektować swoją komunikację, by stymulować konkretne obszary ludzkiego mózgu, co będzie mieć przełożenie na efektywność prowadzonych działań.

\section{Zakończenie}

Rozwój tej gałęzi badań marketingowych warto śledzić ze szczególnym zainteresowaniem. Zmienność otoczenia, której obecnie jesteśmy świadkami, może być jednym z motorów napędowych stymulujących popularyzację tych metod w biznesie. Jak będzie zmieniał się biznes w świetle tego, czego marketerzy dowiedzą się, analizując umysły swoich klientów? Jak rozwijać się będą metody badań jakościowych, te, które dzisiaj dobrze już znamy? Czy badania neuromarketingowe w ciągu kilku najbliższych lat zajmą stałe miejsce wśród pozostałych metod i będą równie często wykorzystywane? Wydaje się, że jednym z głównych wyzwań będą jednak kwestie natury etycznej, które każą szukać cienkiej granicy, która rysuje się pomiędzy wyciąganiem wniosków na podstawie obserwacji zachodzących zjawisk, a wykorzystywaniem technik neuroobrazowania do manipulowania reakcjami odbiorców. Jeśli badacze dojdą do tego punktu, może okazać się, że powrót z niego jest trudniejszy, niż można by przypuszczać.

\section{Literatura}

Angrosino M., 2010, Badania etnograficzne i obserwacyjne, PWN, Warszawa.

Brzezicka J., 2012, Teoria wyboru konsumenta w świetle ekonomii behawioralnej-wybrane zagadnienia, Ekonomia, nr 4. 
Camerer C., Loewenstein G., Prelec D., 2015, Neuroeconomics - how science can inform economics, Journal of Economic Literature, vol. XLIII.

Dąbrowska A., Wódkowski A., 2014, Kompetencje konsumentów w świetle badań ilościowych, Prace Naukowe Uniwersytetu Ekonomicznego we Wrocławiu, nr 336.

Dunaj B. (red.), 1996, Słownik współczesnego języka polskiego, Wilga, Warszawa.

Graves P., 2010, Consumerology the Market Research Myth, the Truth about Consumers and the Psychology of Shopping, Nicholas Brealey Publishing, London.

Gregor B., Kalińska-Kula M., 2015, Badania marketingowe na użytek decyzji menedżerskich, Wydawnictwo Uniwersytetu Łódzkiego, Łódź.

Grzegorczyk W., 2014, Przedmiot i metodyka badań marketingowych $w$ praktyce przedsiębiorstw, Prace Naukowe Uniwersytetu Ekonomicznego we Wrocławiu, nr 337.

Hall H., 2014, Nowy konsument a zmiany $w$ metodach jego badania, Prace Naukowe Uniwersytetu Ekonomicznego we Wrocławiu, nr 336.

Hejduk I., 2010, Sustainability odpowiedzia na kryzys ekonomiczny. Nowe koncepcje przedsiębiorstwa przyszłości, Instytut Organizacji i Zarządzania w Przemyśle ORGMARZ, Warszawa.

Hill D., 2010, Emocjonomika. Wykorzystanie emocji a sukces w biznesie, Rebis, Poznań.

http://www.izmalkowa.com/wp-ontent/uploads/2013/04/IZC_2012_maj_Badania-etnograficzne-w-biznesie-warsztaty_Concordia_Desing.pdf.

Jemielniak D., 2012, Badania jakościowe. Metody i narzędzia, Wydawnictwo Naukowe PWN, Warszawa.

Kaczmarek M., Olejnik I., Springer A., 2013, Badania jakościowe-metody i zastosowania, CeDeWu. pl, Warszawa.

Kahneman D., 2011, Pułapki myślenia. O myśleniu szybkim i wolnym, Media Rodzina, Poznań.

Kotler Ph., Armstrong G., Saunders J., Wong V., 2002, Marketing. Podręcznik europejski, PWE, Warszawa.

Kozielski R., 2013, Wyczucie klienta, Marketing w Praktyce, nr 6.

Kuś G., 2011, Decyzje zakupowe konsumentów a systemu komunikowania, Novae Res, Gdynia.

Maison D., 2010, Jakościowe metody badań marketingowych. Jak zrozumieć klienta, Wydawnictwo Naukowe PWN, Warszawa.

Mazurek-Łopacińska K. (red.), 2005, Badania marketingowe, Wydawnictwo Naukowe PWN, Warszawa.

Niemczyk A., 2004, Konsument we współczesnym świecie, Acta Universitatis Lodziensis, Folia Oeconomica, nr 179.

Szymusiak H., 2012, Neurobiologiczne techniki stosowane w biznesie, Wydawnictwo Uniwersytetu Ekonomicznego w Poznaniu, Poznań.

Wiśniewski R., Brzezicka J., 2013, Ekonomia behawioralna a rynek nieruchomości - teoria i praktyka, Psychologia Ekonomiczna, nr 3.

Zaltman G., 2003, Jak myślą klienci? Podróż w głąb umystu rynku, FORUM, Poznań. 